\title{
LXIII. Some experiments and observations on the colours used in painting by the ancients
}

\section{Sir Humphry Davy LL.D. F.R.S.}

To cite this article: Sir Humphry Davy LL.D. F.R.S. (1815) LXIII. Some experiments and observations on the colours used in painting by the ancients, Philosophical Magazine Series 1 , 45:205, 349-359, DOI: 10.1080/14786441508638450

To link to this article: http://dx.doi.org/10.1080/14786441508638450

册 Published online: 27 Jul 2009.

Submit your article to this journal $\sqsubset \pi$

Џ Article views: 5

Q View related articles 5 
and the azote, remaining combined by pairs in each particle of chlore; so that a volume of this gas is equivalent to two volumes of another gas relative to combinations; and that if the tetrahedrons of the chlore shall all be separated from each other, we shall obtain, by the decomposition of the euchlorine, six volumes of chlore and two volumes of oxygen, precisely as we find in the residue from the decomposition of ammonizcal gas, the particles of which have the same representative form with that of the euchlorine, six volumes of oxygen and two of azote.

The results which I have just indicated form but a very small part of those which we may deduce from the consideration of the representative forms of the particles of boties applied to the determination of the proportions of inorganic compounds. The chemistry of organized bodies also presents numerous applieation of this theory; but it is in this respect particularly that there are many analyses and calulations to make for completing it. I have nevertheless drawn several determinations relative to the composition of different circumstances drawn from the vegetable kinglom, which agree too strongly with the results of experience to leave any doubts as to the utility of which it may be in this part of chemistry.

LXIII. Some Experiments and Olservations on the Colours used in Painting by the Ancients. By Sir Humphry Davy, LL.D. F.R.S.**

\section{T I. Introduction.}

The importance the Greeks attached to pictures, the estimation in which their great painters were held, the high prices paid for their most celebrated productions, and the emulation existing between different states with regard to the possession of them, prove that painting was one of the arts most cultivated in ancient Greece : the mutilated remains of the Greek statues, notwithstanding the efforts of modern artists during three centuries of civilization, are still contemplated as the models of perfection in sculpture; and we have no reason for supposing an inferior degree of excellence in the sister art, amongst a people to whom genius and taste were a kind of birthright, and who possessed a perception, which seemed almost instinctive, of the dignified, the beautiful, and the sublime.

The works of the great masters of Greece are unfortunately entirely lost. They disappeared from their native country du ring the wars waged by the Romans with the successors of Alexander, and the later Greek republics ; and were destroyed

* From the Ptilosophieal Transactions for 1815, part i. 
either by aceident, by time, or by barbarian conquerors at the period of the decline and fall of the Roman Empire.

The subjects of many of these pictures are described in ancient authors, and some idea of the manner and style of the Greek artists may be gained from the designs on the vases, improperly called Etruscan, which were executed by artists of Magna Gracia, and many of which are probably copies from celebrated works: and some faint notion of their execution and colouring may be gained from the paintings in fresco found at Rome, Herculaneum, and Pompeii.

These.paintings, it is true, are not properly Greek ; yet, whatever may be said of the early existence of painting in Italy as a native art, we are certain that, at the period when Rome was the metropolis of the world, the fine arts were cultivated in that city exclusively by Greek artists, or by artists of the Greek schools. By comparing the descriptions of Vitruvius* and Pliny with those of Theophrastust, we learn that the same materials for colouring were employed at Rome and at Athens; and of thirty great painters that Pliny mentions whose work were known to the Romans, two only are expressly mentioned as born in Italy, and the rest were Greeks. Ornamental fresco painting was indeed generally exercised by inferior artists; and the designs on the walls of the houses of Herculaneum and Pompeii, towns of the third or fourth order, can hardly be suppesed to offer fair specimens of excellence, even in this department of the art : but in Rome, in the time of her full glory, and in the ornaments of the imperial palace of the first Casars, all the resources of the distinguished artists of that age were probably employed. Pliny names Comelius Pinus and Accius Priscus as the two artists of the greatest merit in his own time, and states that they painted the Temple of Honour and Virtue $f$, «Imperatori Vespasiano Augusto restituenti;" and it is not improbable that these artists had a share in executing, or directing the execution of, the paintings and ornaments in the baths of Titus; and at this period the works of Zeuxis, Parrhasius, 'Timanthes, Apelles, and Protagoras were exhibited in Rome, and must have guided the taste of the artists. The decorations of the baths were intended to be seen by torch-light, and many of them at a considerable elevation, so that the colours were brilliant and the contrast strong; yet still these works are regarded by connoisseurs as performances of considerable excellence: the minor ornaments of them have led to the foundation of a style in painting which might with much more propriety be called Romanesque than Arabesque : and no greater eulogy can be bestowed upon them

* De Architectura, lib. vii. cap. 5.

1 Plin. Nat. Hist, lib. xxxv. cap. 37.

† De Lapidibus. 
than the use to which they have been applied by the greatest painter of modern times, in his exquisite performances in the Vatican. In these and in other works of the same uge, the effect of the ancient models is obvious ; and the various copies and imitations that have been made of these remains of antiquity have transferred their spirit into modern art, and left little to be desired as to those results which the skill of the painter can command. There remains, however, another use to which they may be applied, that of making us acquainted with the nature and chemical composition of the colours used by the Greek and Roman artists. The works of Theophrastus, Dioscorides, Vitruvitus, and Pliny, contain descriptions of the substances used by the ancients as pigments; but hitherto, I believe, no experimental attempt has been made to identify them, or to imitate such of them as are peculiar*. In the following pages I shal! have the honour of offering to the Society an investigation of this subject. My experiments have been made upon colours found in the baths of Titus, and the ruins called the baths of Livia, and in the remains of other palaces and baths of ancient Rome, and in the ruins of Pompeii. By the kindness of my friend, the celebrated Canova, who is charged with the care of the works connected with ancient art in Rome, I have been enabled to select, with my own hands, specimens of the different pigments that have been found in vases discovered in the excavations lately made beneath the ruins of the palace of Titus, and to compare them with the colours fixed on the walls or detached in fragments of stucco: and Signor Nelli, the proprietor of the Nozze Aldobrandine, with great liberality permitted me to make such experiments upon the colours of this celebrated picture, as were necessary to determine their nature. When the preservation of a work of art was concerned, I made my researches upon mere atoms of the colour, taken from a place where the loss was imperceptible: and without having injured any of the precious remains of antiquity, I flatter myself, I shall be able to give some information not without interest to scientifie men as well as to artists, and not wholly devoid of practical applications.

* In the 7oth volume of the Annales de Chimie, page Q2, M. Chaptal has published a paper on seven culours found in a colour-shop at Pompeit. Four of these he found to be natural colours, ochres, a specimen of Verona green, and one of punice stone. Two of them were blues, which he considers as compounds of alumine and lime with oxide of copper, and the last a pale rose colour, which he regards as anklogous to the lake formed by fxing the colouring matter of madder upon alumine. I shall againr refer to the observations of $M$. Chaptal in the course of this paper. It will be found on perusal, that they do not supersede the inquiry mentioned in the text. 


\section{I1. Of the Red Colours of the Ancients.}

Amon; gst the substances found in a large earthen vase flled with mixtures of different colours with clay and chalk, found about two years ago in a chamber at that time opened in the baths of Titus, are three different kinds of red; one bright and approacling to orange, another dull red, a third a purplish red*. On exposing the bright red to the flame of alcohol, it became darker red; and on increasing the heat by a blow-pipe, it fused into a mass having the appearance of litharge, and which was proved to be this substance by the action of sulphuric and muriatic acids. This colour is consequently minium, or the red oxide of lead.

Un exposing the dull red to heat, it became black, but on cooling recovered its former tint. When heated in a glass tube it afforded no volatile matter condensible by cold but water. Acted on by muriatic acid, it rendered it yellow; and the acid, after being heated upon it, vielded an orange- coloured precipitate to ammonia. When fised with hydrate of potassa, the colour rendered it yellow; and the mixture acted on by nitric acid afforded silica and orange oxide of iron. It is evident from these results that the dull red colour is an iron ochre.

The purplish red submitted to experiments, exhibited similar phrnomena, and proved to be an ochre of a different tint.

In examining the fresco paintings in the baths of Titus, 1 found that these colcurs had been all of them used, the ochres particularly, in the shades of the figures, and the minium in the ornaments on the borders.

1 found anotiler red on the walls, of a tint different from those in the vase and much brighter, and which had been employed in various apartments, and formed the basis of the colouring of the niche and other parts of the chamber in which the Laocoon is said to have been found. On scraping a little of this colour from the wall, and submitting it to chemical tests, it proved to be vermilion or cinnabar, and on heating it with iron flings, running quicksilver was procured from it.

I found the same colour on some fragnents of ancient stueco in a vineyard near the pyramidal monument of Caius Cestius.

In the Nozze Aldobrandine, the reds are all ochres. I tried on these reds the action of acids, of alkalies, and of chlorine, but could discover no traces either of minium or vermilion in this picture.

Minium was known to the Greeks under the name of $\sigma \alpha v \delta \alpha-$ $\rho^{\prime} x \not \gamma \dagger$, and to the Romans under that of cerussa usla. It is said,

* Nearly of the samac tint as prussiate of copper.

f Dioscorides, lab. v. 122 . 
by Pliny $*$ t $n$ have been discovered accidentally by means of a fre that took p'ace at the Piræus at Athens. Some ceruse which had been exposed to this fire was found converted into minium, and the process was artificially imitated: and he states that it was first used as a pigment by Nicias $\uparrow$.

Several red earths used in painting are described by Theophrastus, Vitruvius $\ddagger$, and Pliny. The Sinopian earth, the Armenian earth, and the African ochre, which had its red colour produced by calcination.

Cinnabar or vermilion was called by the Greeks xเvyábeab $\S$, and by the Romans minium. It is said by Theophrastus $\|$ to have been discovered by Callias, an Atheman, ninety years before Praxibulus, and in the 349th year of Rome, and was prepared by washing the ores of quicksilver. According to Pliny 7 , who quotes Verrius, it was a colour held in great esteem in Rome at the time of the Republic; on great festivals it was used for painting the face of Jupiter Capitolinus, and likewise for colouring the body of the victor in the triumphal processions, "sic Camillum triumphasse**." Pliny mentions that even in his time vermilion was always placed at triumphal feasts amongst the precious ointments; and that the first occupation of new censors of the Capitol was to fill the place of verinilion-painter to Jupiter.

Vermilion was always a very dear colour amongst the Romans; and we are informed by Pliny, that to prevent the price from being excessive it was fixed by the government. The circumstance of the chambers in the baths of Titus being covered with it, affords proof in favour of their being intended for imperial use; and we are expressly informed by the author I have just quoted, that the Laocoon, in his time, was in the palace of Titus $+\dagger$ : and the taste of the ancients in selecting a colour to give full effect to their master-pieces of sculpture was similar to that of a late celebrated English connoisseur.

Pliny describes a second or inferior sort of vermilion formed by calcining stone found in veins of lead. It is evident that this substance was the same as our minium, and the Roman cerussa usta, and the stones alluded to by Pliny must have been carbonate of lead: and he states distinctly, that it is a substance which becomes red only when burnt.

* Lib. xxxv. cap. 20. + Id. ibid.

t De Architectura, lib. vii, cap. 7. Dioscorides, lib. v. cap. 109.

|| De Lapid. cap. 104.

If Lib. axxiii. cap. 36. Nunc inter pigmenta magna auctoritatis, et quondan apud Romranos non solum maxime, sed etiam sacra. * Ihid.

† Lib. xxxvi. cap. 4. Sicut in Laocoonte, qui est in Titi Imperatol is dome, opus omnibus et pirture et statuarian artis praponentum.

Vol. 45. No. 205: May 1815.

Z

III, $O f$ 


\section{Of the Yellows of the Ancients.}

A large earthen pot found in one of the chambers of the baths of Titus contains a quantity of a yellow paint, which, submitted to chemical examination, proved to be a mixture of yellow ochre with chalk or carbonate of lime.

This colour is used in considerable quantities in different parts of the batbs; but principally in the least ornamented chambers, and in those which were probahly intended for the use of the dnmestics. In the vase to which I alluded in the last section, $I$ found three different yellows; two of them proved to be yellow ochres mised with different quantities of chalk, and the third a yellow ochre mixed with red oxide of lead, or minium.

The ancients procured their yellow ochre* from different parts of the world; but the nost esteemed, as we are informed by Pliny, was the Athenian ochre; and it is stated by Vitruvius, that in his time the mine which produced this substance was no longer worked.

The ancients had two other colours, which were orange or yellow; the auripigmentum, or ágosvirov, said to approach to old in its colour, and which is described by Vitruvius $\uparrow$ as found native in Pontus, and which is evidently sulphuret of arsenic: and a pale sandarach, said by Pliny to have been found in gold and silver mines, and which was imitated at Rome by a partia! calcination of ceruse, and which must have been massicot, or the yellow oxide of lead mixed with minium. That there was a colour called by the Romans sandarach, different from pure minium, is evident from what Pliny says; namely, that the palest kind of orpiment resembles sandarach, and from the line of Nævius, one of the most ancient Latin poets, "Merula sandaracino ore :" so that this colour must have been a bright yellow similar to that of the beak of the blackbird $\ddagger$. Dioscorides describes the best $\sigma a y \delta \alpha \rho^{\prime} \alpha \eta$ as approaching in colour to vermilion $\S$, and the Greeks probably always applied this term to minium; bhat the Romans seem to have used it in a different sense; and some confusion was natural when different colours were prepared from the same substance by different degrees of calcination.

I have not detected the use of orpiment in any of the ancient fresco paintings; but a deep yellow approaching to orange, which covered a piece of stucco in the ruins near the monument of Caius Cestius, proved to be oxide of lead, and consisted of massicot mixed with minium. It is probable that the ancients used many colours from lead of different tints between the usta of

- äxea, Thzophrastus de Lapidibus.

$\$$ Histoire de la Peinture ancienne, page 199. $\uparrow$ Vitruvius, lib. vii. Lib, v. 122. 
Pliny, which was our minium, and imperfectly decomposed ceruse, or pale massicot.

The yellows in the Aldobrandini picture are all ochres. I examined the colours in a very spirited picture, on the wall of one of the houses at Pompeii, of a lion and a man; they all proved to be red and yellow ochres.

\section{Of the Biue Colours of the Ancients.}

Different shades of blue are userl in the different apartments of the baths of Titus, and several very fine blues exist in the mixtures of colours to which I have referred in the last two sections.

These blues are pale or darker, according as they contain larger or smaller quantities of carbonate of lime; but when this carbonate of lime is dissolved by acids, they present the same body colour, a very fine blue powder similar to the best smalt or to ultramarine, rough to the touch, and which does not lose its colour by being heated to redness; but which becomes agglutinated and senifused at a white heat.

This blue I found was very little acted on by acids. Nitromuriatic acid by being long boiled upon it gained, however, a slight tint of yellow, and afforded proofs of the presence of oxide of eopper.

A quantity of the colour was fused for half an hour with twice its weight of hydrate of potassa; the mass, which was blueish green, was treated by muriatic acid in the manner usually employed for the analysis of siliceous stones, when it afforded a gluantity of silica equal to more than 3-5ths of its weight. The colouring matter readily dissolved in solution of ammonia, to which it gave a bright blue tint, and it proved to be oxide of copper. The residuum afforded a considerable quantity of alumine, and a small quantity of lime.

Amongst some rubbish that had been collected in one of the chambers of the baths of Titus, I found several large lumps of a deep blue frit, which when powdered and mixed with chalk produced colours exactly the same as those used in the baths, and which when submitted to chemical tests were found to be the same in composition.

The minute quantity of lime found in this substance was not sufficient to account for its fusibility: it was therefore reasonable to expect the presence of a fixed alkali in it; and on fusing some of it with three times its weight of boracic acid, and treating the mass with nitric acid and carbonate of ammonia, and afterwards distilling sulphuric acid from it, I procured from it sulphate of soda; which proves that it was a frit made by means of soda, and coloured with oxide of copper.

The undiluted colour in its form of frit is used for ornamenting $Z 2$ some 
some of the mouldings detached from the ceilings of the chambers in the baths of Titus: and the walls of one chamber between the compartments of red marble, bear proofs of having been covered with this frit, and retain a considerable quantity of it.

There is every reason to believe that this is the colour described by Theophrastus as discovered by an Egyptian king*; and of which the manufactory is said to have been anciently established at Alexandria.

Vitruvius speaks of it, under the name of ceruleumt, as the colour used commonly in painting chambers, and states, that it was made in his time at Puzzuoli, where the method of fabricating it was.brought from Egypt by Vestorius; he gives the method of preparing it by heating strongly together sand, flos nitri $t$, and filings of copper.

Pliny mentions other blues, which he calls species of sand (arence) from the mines of Egypt, Scythia, and Cyprus. These natural blues, there is reason to believe, were different preparations of lapis lazuli, and of the bluc carbonates and arseniates of copper.

Both Pliny and Vitruvius speak of the Indian blue, which the first author states to be combustible, and which was evidently a species of idigo.

I have examined several blues in the fragments of fresco painting from the ruins near the monument of Caius Cestius. In a deep blue approaching in tint to indigo, I found a little carbonate of copper, but the basis of this colour was the frit before described.

The blues in the Nozze Aldobrandine, from their resisting the action of acids, and from the effects of fire, $I$ am inclined to consider as composed of the Alexandrian or Puzzuoli blue.

In an excavation made at Ponpeii, in May 1814, at which I was prescnt, a small pot containing a pale blue colour was dúg up, which the exalted personage, by whose command the excavation was made, was so good as to put into my hands. It proved to be a mixture of carbonate of lime with the Alexandrian frit $\S$.

Vitruvius states, that the ancients had a mode of imitating the Indian blue or indigo, by mixing the powder of the glass called by the Greeks vados, with selinusian "creta" or annularian "creta," which was white clay or chalk mixed with stained glass; the same practice is likewise referred to by Pliny.

* De Lapidibus, sect. xcriii.

I This identilies the nitrum. + Lib. vii. cap. 11.

This probably is the

did The examined by M. Chaptal. 'Te did not search in it for alkali, or there is every reason to suppose he would have found soda. 
There is much reason for supposing that this stained glass, or ia 05 , was tinged with oxide of cobalt; and that these colours were similar to our smalt. I have not found any powdered colour of this kind in the baths of Titus, or in any other Roman ruins; but a blue glass tinged with gobalt is very common in those ruins, which when powdered forms a pale smalt.

I have examined many pastes and glasses that contain oxide of copper; they are alt blueish green, green, or of an opaque watery blue. The transparent bltte glass vessels which are found with the vases in the tombs in Magna Gracia are tinged with cobalt; and on analysing differeut ancient transparent blue glasses which Mr. Millingen was so good as to give me, I foụnd cobalt in all of them*.

Theophrastus, in speaking of the matufacture of glass, states as a report that " $\chi \chi^{\alpha \lambda \times o_{s}}$ " was used to give it a fine colour, and it is extremely probable that the Greeks took cobalt for a species of $x^{\alpha \lambda x}{ }^{2} s$. I bave examined some Egyptian pastes which are all tinged blue and green with copper; but though $\mathbf{I}$ have made experiments on nine different specimens of ancient Greek and Roman transparent blue glass, I have not found copper in any, but cobalt in all of them $\uparrow$.

\section{Of the ancient Greens.}

The ceiling of the chambers called the Baths of Livia is highly ornamented with gilding and paintings; the larger paintings have been removed, but the ground-work and the borders remain. A fragment detached from the borders, which appears of the same colour as the ground-work, was of a deep sea green. The colouring matter examined, proved to be soluble in acids with effervescence; and when precipitated from acids, it redissolved in solution of ammonia, giving it the bright blue tint produced by oxide of copper. There are several different shades of green employed in the bath; of Titus, and on the fragments found near the momunent of Cains Cestius: in the vase of mixed colours I found three different varieties; one, which approached to olive, was the common green earth of Verona; another, which

- The mere fusion of these glasses with alkali and digestion of the product with muriatic acid was sufticient to produce a sympathetic ink from them; even the silica separated by the acid yaucd a faint blue green tint by heat, and the solution in muriatic acid became permanently green by the action of sulphuric acid, a phenomewon Dr. Marcet has observed as belonging to the muriate of cobalt.

+ A gentleman at Milan informed me last summer, that he had found oxide of cobalt in the blue glass found in the ruins of Hadrian's villa, and at thistime $I$ ball no idea that cobalt was known to the ancients. $M$ r. Hatchett and $\mathrm{MH}$. Klaprocb lad both found oxide of copper in some ancient blue glasses, which I conceive must have been opaque. 
was pale gtass green, had the character of carbonate of copper mixed with chalk; and a third, which was sea green, was a green combination of copper mixed with the blue copper frit.

All the greens that I examined on the walls of the baths of Titus were combination of copper. From the extreme brilliancy of a green which I found in the vineyard to which I have so often referred, I suspected that it might contain arsenious acid, and be analogous to Scheele's green; but on submitting it to experiments, it afforded no indications of this substance, and proved to be a pure carbonate of copper.

The greens of copper were well known to the Greeks; the most esteemed is described by Theophrastus and Dioscorides under the name of $\chi g^{\text {voroxón }} \lambda \lambda \alpha$, and is stated by both to be found in metallic veins.

Vitruvius mentions chrysocolla as a native substance found in copper mines, and Pliny speaks of an artificial chrysocolla made from the clay found in the neighbourhood of metallic veins, which clay was most probably impregnated with copper. He describes it as rendered green by the herb luteum. There is every reason to believe, that the native chrysocolla was carbonate of copper, and that the artificial was clay impregnated with sulphate of copper rendered green by a yellow dye.

Some commentators have supposed that chrysocolla is the same substance as borax, because Pliny has mentioned that a preparation called by this name was used by goldsmiths for soldering gold*; but nothing can be more gross than this mistake, which, however, has been copied into many elementary books of chemistry. The material used for soldering gold consisted of carbonate or oxide of copper mixed with alkaline phosphates. This is evident from the description of Dioscorides " $\Pi_{\varepsilon g \text { i }}$ wö

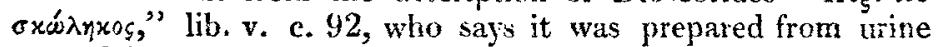
treated in brass mortars. Pliny says likewise, that it was prepared from "Cypria ærugine et pueri impubis urina, addito nitrot." The name of chrysocolla was probably derived from the green powder used by the goldsmiths, and which contained carbonate of copper as one of its ingredients $t$.

Amongst the substances found in the baths of Titus were some masses of a grass green colour. I at first thought these might

- Itist. de la Peinture ancienne, pag. 38. "Nos droguistes la nomme Borax." + Lib. xxxiii. cap. 5.

I The commentators have been likew ise misled by Pliny's description, "chrysocolla humor est in puteis per venam auri defluens. \&c." Itid.; but this is merely an inaccurate accout of the deconsposition of a rein containing copper. We have no reason for supposing that the Greeks and Romans were acquainted with borax. Pliny, probalily misled by the application of the same name to different substances, considered clirysocolla as the coment of gold in minera! reins. 
The Electric Columen considered as a maintaining Power. 359

be specimens of native chrysocolla; they proved indeed to to carbonate of copper, but it had formed round longitudinal nuckei of red oxide of copper, so that probably these substances hed been copper nails or small pieces of copper used in the building, converted by the action of the air, during so many centuries, into oxide and carbonate.

The ancients, as it appears from Theophrastus, were well acquainted with verdigrise. Vitruvius mentions it amongst pigments; and probably muny of the ancient greens, which are now carbonate of copper, were originally laid on in the state of acetite.

The ancients had beautiful deep green glasses, which I find are tinged with oxide of copper; but it does not appear that they used these glasses in a state of powder as pigments.

The greens of the Aldobrandini picture are all of copper, as was evident from the action of the muriatic acid upon them.

[To be continued.]

LXIV. The Electric Column considered as a maintaining Power, or First Mover for mechanical Purposes. By Geongs JOHN SNGEK, Esq.

II $\Gamma_{\text {If }}$ power of the electric column as a souree of mechanical action, was first discovered and applied by that excellent philosopher M. De Lue, the admirable inveutor of that important instrumeut; and it is to his active discrimination and unceasing exertions we are indebted for the principal mechanical arrangements which have been employed to render the variable action of the column equal to the production of a constant though unequal motion.

The principal object of such an attempt is to enable an observer to measure the actual variation in the power of the column at different times, and under dissimilar cireumstances; and, by a comparison of these changes with the usinl meteorological phænomena, to ascertain if any connexion can be traced between the spontaneous electricity of the column, and the natural eleciricity of the earth and the atmosphere.

For this purpose any arrangement may be emploved which is capable either of producing or maintaining the motion of light substances by the immediate action of the column; and that will be most eligib:o which protuces this effect most certainly, and by the least con. ylex means.

With columns of small power, the frequency with which the Jeaves of Bennet's electrometer are made to open, and strike the « 4 sides 